\title{
Congenital Isolated Thyroid Stimulating Hormone Deficiency
}

National Cancer Institute

\section{Source}

National Cancer Institute. Congenital Isolated Thyroid Stimulating Hormone Deficiency. NCI Thesaurus. Code C120449.

Thyroid stimulating hormone (TSH) deficiency associated with mutations(s) in the TSHB gene that encodes thyrotropin subunit beta. 